\title{
Update on complications of synthetic suburethral slings
}

\author{
Cristiano Mendes Gomes ${ }^{1}$, Fabrício Leite Carvalho ${ }^{1}$, Carlos Henrique Suzuki Bellucci ${ }^{1}$, Thiago Souto \\ Hemerly ${ }^{1}$, Fábio Baracat ${ }^{1}$, Jose de Bessa Jr. ${ }^{1}$, Miguel Srougi ${ }^{1}$, Homero Bruschini ${ }^{1}$ \\ ${ }^{1}$ Divisão de Urologia, Faculdade de Medicina da Universidade de São Paulo, São Paulo, Brasil
}

\section{ABSTRACT}

Synthetic suburethral slings have become the most widely used technique for the surgical treatment of stress urinary incontinence. Despite its high success rates, significant complications have been reported including bleeding, urethral or bladder injury, urethral or bladder mesh erosion, intestinal perforation, vaginal extrusion of mesh, urinary tract infection, pain, urinary urgency and bladder outlet obstruction. Recent warnings from important regulatory agencies worldwide concerning safety issues of the use of mesh for urogynecological reconstruction have had a strong impact on patients as well as surgeons and manufacturers. In this paper, we reviewed the literature regarding surgical morbidity associated with synthetic suburethral slings.

\section{ARTICLE INFO}

\section{Keywords:}

Urinary Incontinence;

Polypropylenes; Postoperative

Complications

Int Braz J Urol. 2017; 43: 822-34

Submitted for publication:

April 28, 2016

Accepted after revision:

December 05, 2016

Published as Ahead of Print:

January 25, 2017

\section{INTRODUCTION}

Stress urinary incontinence (SUI) is defined as the involuntary leakage of urine with effort or exertion, such as physical exercise, sneezing or coughing (1). Approximately 50\% of all women experience SUI symptoms (1), and many of these women are sufficiently bothered by their symptoms to seek treatment from a physician. Pelvic floor muscle exercises and other nonsurgical treatments can be effective therapies, but many women choose to undergo surgery to treat their SUI symptoms. Suburethral synthetic sling (SSS) placement is the most common surgery currently performed for SUI and extensive data support their use for the treatment of female SUI. Compared to other surgical techniques, the advantages include shorter operati- ve time/anesthetic need, reduced surgical pain and hospitalization time, and lower incidence of postoperative voiding dysfunction (2-10), The technique is based on the placement of a thin tape of synthetic mesh under the middle urethra which is passed through the retropubic space with a passing needle and exits the abdominal wall just above the pubis (Figure-1). It was introduced by Petros and Ulmsten in 1996 (11). By 2007, over 1.200.000 SSS had been performed worldwide and the numbers continue to increase exponentially $(12,13)$. A significant modification of the technique was the use of a transobturator route for the placement of the synthetic tape which was introduced by Delorme in 2001 (Figure-2) (14). The purpose of that was to eliminate the risks of complications associated with the passage of a needle in the retropubic space. 
Figure 1 - Haematoma of the right thigh (arrow) on postoperative day 3 of a transobturator SSS, with spontaneous resolution.

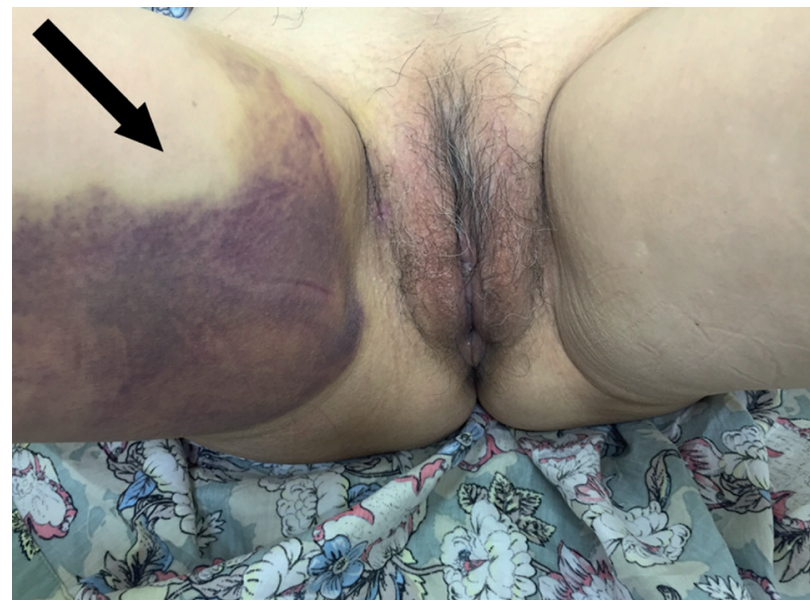

Figure 2 - CT scan in the first postoperative day following a retropubic SSS demonstrates large pelvic hematoma (arrow) compressing the bladder laterally.

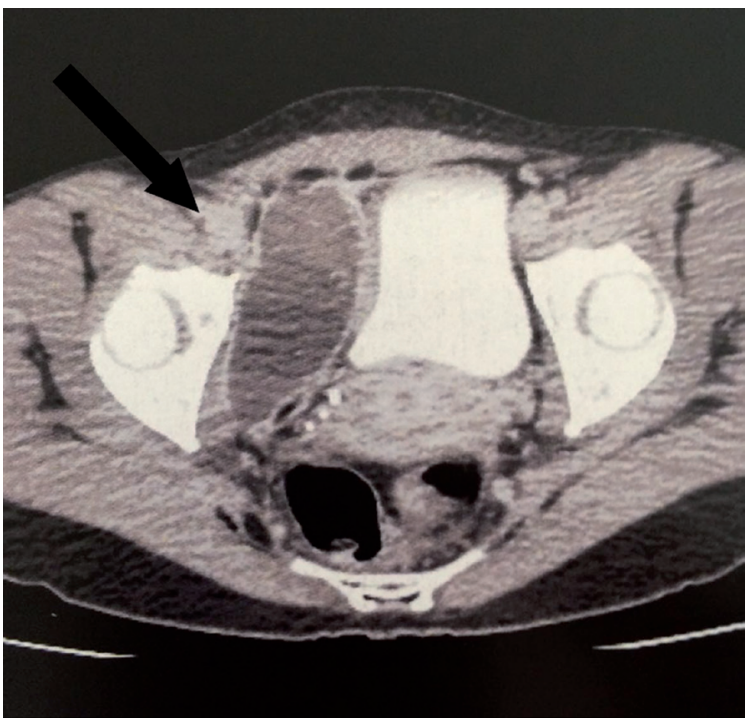

In the American Urological Association's opinion, any restriction of the use of SSS would be a disservice to women who choose surgical correction of SUI (15). However, despite the high success rates of the technique, a growing number of complications and adverse effects have been reported (9, 16-26). Recent reports indicate complication rates of $4.3 \%$ to $75 \%$ for the retropubic slings $(2,18)$ and $10.5 \%$ to $31.3 \%$ for the transobturator ones (Table-1) (27-30).
Complications associated to SSS can be classified as immediate or late. Immediate complications include injuries during surgery as well as urinary retention and postoperative infections. Lesions may involve blood vessels, bladder, bowel, urethra, and nerves. Late complications occur weeks or months after surgery and include bladder outlet obstruction, urgency or urge-incontinence, recurrent urinary infections, erosion of the synthetic mesh to the urethra or bladder and extrusion of the tape to the vagina (31).

In a recent communication, the United States Food and Drug Administration (FDA) released an update on the safety and effectiveness of transvaginal placement of mesh (32). Although it was mainly directed to the placement of mesh for the treatment of pelvic organ prolapse, the use of mesh for the treatment of SUI was also included. The communication informed that mesh complications are not rare in transvaginal surgeries and may include serious adverse events (32). As a consequence, meshes from important manufacturers have been removed from the market. Moreover, women have been increasingly worried about the safety of SSS since they do not properly understand the differences between using mesh to treat pelvic organ prolapse as opposed to SUI.

\section{MATERIALS AND METHODS}

There is a large body of evidence and review articles evaluating the complications of SSS. The goal of the current study was not to conduct a complete or systematic review or meta-analysis of the topic, but rather to perform a comprehensive overview based on published original and review articles augmented by a literature search. We performed a MEDLINE literature review using the "MeSH" (Medical Subject Heading) and "free text" protocols. The MeSH search was conducted with the following terms: "suburethral sling", "surgical tape", "urinary incontinence", "female". Multiple "free text" searches were performed using the following terms individually through all fields of the records: "sling", "midurethral sling", "transvaginal tape", "transobturator tape", "tension-free tape". The search was restricted to the English language. 
Table 1 - Postoperative complication rates after syntethic suburethral sling surgery.

\begin{tabular}{|c|c|c|}
\hline Complication & Retropubic & Transobturatory \\
\hline Bleeding & 0.7 to $8 \%(27,29,45,81,83)$ & $0-2 \%(27,29,36,37)$ \\
\hline Bladder Injury & 0.7 to $24 \%(28,47)$ & $0-15 \%(12,29,48-50)(12,29,48-50)$ \\
\hline Urethral Injury & 0.07 to $0.2 \%(44,45)$ & 0.1 to $2.5 \%(36,51)$ \\
\hline Urethral Erosion & $0.03-0.8 \%(45,52)$ & 0.03 to $0.8 \%(45,52)$ \\
\hline Intestinal Injury & 0.03 to $0.7 \%(18,63-65)$ & $0 \%$ \\
\hline Vaginal Erosion & $0-1.5 \%(28,29)$ & 0 to $10.9 \%(27,29,66,67)$ \\
\hline UTI & 7.4 to $13 \%(4,27,28,37)$ & 7.4 to $13 \%(4,27,28,37)$ \\
\hline Pain & $4 \%(75)$ & $9.4 \%(75)$ \\
\hline Urgency "de novo" & $0,2 \%-25 \%(28,81,82)$ & 0 to $15.6 \%(27,28,83)$ \\
\hline Bladder Outlet Obstruction & 6 to $18.3 \%(12,24,26,75,94)$ & $3.0-11 \%(12,24,26,75,94)$ \\
\hline Urinary Retention & $4.1 \%-19.5 \%(2,28,29)$ & $2.7 \%-11 \%(28,29,37)$ \\
\hline
\end{tabular}

We divided the results in different topics regarding complications of synthetic suburethral slings, including bleeding, bladder and urethral injuries, bladder and urethral erosions, bowel injury, vaginal extrusion, urinary tract infection, postoperative pain, de novo urgency, urinary retention and bladder outlet obstruction.

\section{RESULTS}

\section{Bleeding}

The difficulty in reporting bleeding rates begins by defining this complication. It may vary from a simple hemorrhage during periurethral dissection that is self-limited and easily contained by compression to major vascular injuries with hemodynamic instability requiring aggressive treatment. The reports range from vaginal haematomas (Figure-1) to large vessel injuries with catastrophic outcomes (33). Insignificant haematomas may be common postoperatively after retropubic slings, and are occasionally found in 25\% of patients undergoing magnetic resonance imaging (34). Haematomas of less than $100 \mathrm{~mL}$ are rarely symptomatic, while the larger ones frequently cause abdominal discomfort (35).

Overall, bleeding rates vary from $0.7 \%$ to $8 \%$ for the retropubic slings and from $0 \%$ to $2 \%$ for the transobturator slings $(24,27,36)$. Large series $(28,37-39)$ and metanalyses $(24,33,40)$ have shown a significant lower risk of hemorrhagic complications with the transobturator technique. Deng et al. (41), reviewing twenty-eight series from 2001 to 2005 , identified that $0.1 \%$ of the patients required blood transfusion.

Large haematomas in the retropubic space usually require surgical drainage (Figure-2), since aspiration appears to be ineffective $(2,35,42)$. Injuries to major vessels during surgery require immediate surgical exploration with repair, ligation or reconstruction when possible (2). However, intraoperative bleeding is usually mild to moderate and under these circumstances transvaginal exploration is frequently ineffective and should be avoided. Since most of these cases are effectively managed by vaginal packing, the surgeon facing this complication should try and complete the procedure as fast as he can. Rarely, endovascular embolization has been used for the treatment of hemorrhagic complications of SSS surgery (43).

\section{Bladder and urethral injuries}

Bladder injury during SSS surgery occurs in 2.7 to $6 \%$ of the patients $(44,45)$. Perforation by the needle is generally the cause of the lesion, which is thus more frequent at the lateral bladder walls (Figure-3). Rarely, the lesion may occur at the time of vaginal dissection and, in this circumstance, the bladder base is affected and the diagnosis is made by the observation of urine drainage at the injury site. 
Figure 3 - Cystoscopic view of sling mesh (arrow) in the bladder after a retropubic sling surgery.

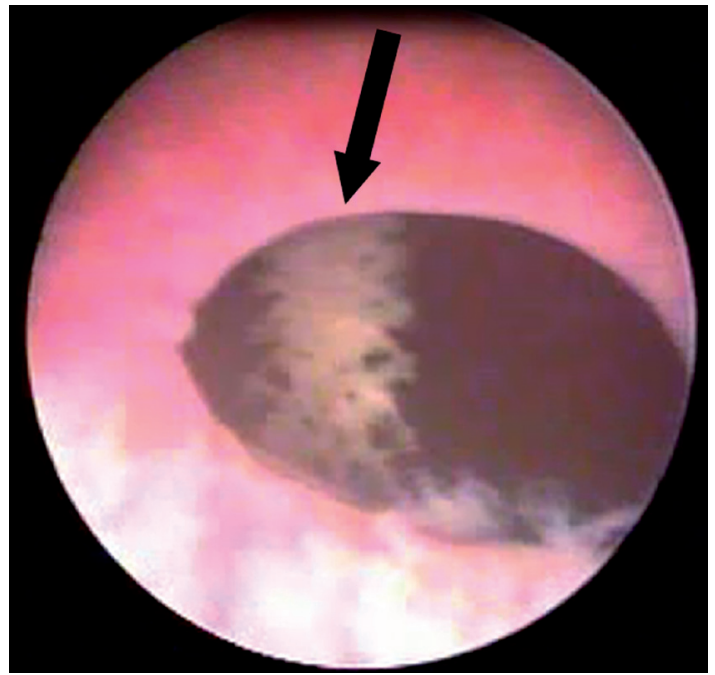

Risk factors for bladder injury are previous antiincontinence surgery, previous surgeries in the retropubic space and surgeon inexperience (46). For retropubic slings, the incidence ranges from 0.7 to $24 \%(28,47)$, while for transobturator slings, the reported rates vary from $0 \%$ to $15 \%$ (12, 48-50). Most bladder perforations, if recognized during surgery, are treated by repositioning the needle and maintaining bladder drainage with a Foley catheter for 2-7 days (51).

Intraoperative urethral injury occurs in $0.07 \%$ to $0.2 \%$ for retropubic slings $(44,45)$ and $0.1 \%$ to $2.5 \%$ for transobturator $(36,52)$. It usually occurs during vaginal dissection of the paraurethral space and the diagnosis is made by visualization of the Foley catheter. However, inadvertent needle passage is also a possible cause. In these cases, the diagnosis is made during urethrocystoscopy. The lesion must be repaired immediately and placement of a synthetic sling at the same surgery is contraindicated (15). Prolonged bladder drainage with a Foley catheter (7-14 days) is recommended $(51,53,54)$.

\section{Bladder and urethral erosion}

Erosion is the extrusion of synthetic mesh to the lumen of the bladder or urethra, which occurs in the late postoperative period. Urethral erosion rates vary from $0.03 \%$ to $0.8 \%$ (45, 55). Typically, patients with bladder or urethral erosion present filling lower urinary tract symptoms such as urgency and urinary frequency, pelvic pain, dyspareunia, recurrent urinary tract infections, voiding symptoms and microscopic hematuria. Some cases with late diagnosis, may in fact be secondary to urethral or bladder injury during surgery that was overlooked. The eroded mesh may be calcified and present as a fixed bladder stone (Figure-4a). These patients may remain asymptomatic for several months, or present mild symptoms that increase gradually. The diagnosis of urethral or bladder erosion is confirmed by urethrocystoscopy (Figure-4b).

Late urethral erosion is caused by excessive tension of the sling under the urethra, leading to progressive atrophy and subsequent erosion. Hypoestrogenism, prior vaginal or

Figure 4a - Pelvic CT scan shows calcified sling tape (arrow) eroding the bladder wall at the left side 2 years after a retropubic SSS.

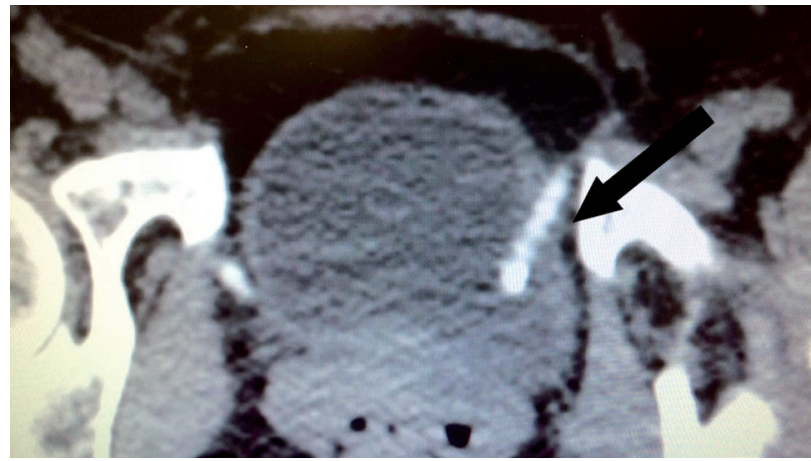

Figure 4b - Mesh erosion in the urethra found in urethrocystoscopy two years after SSS (arrow).

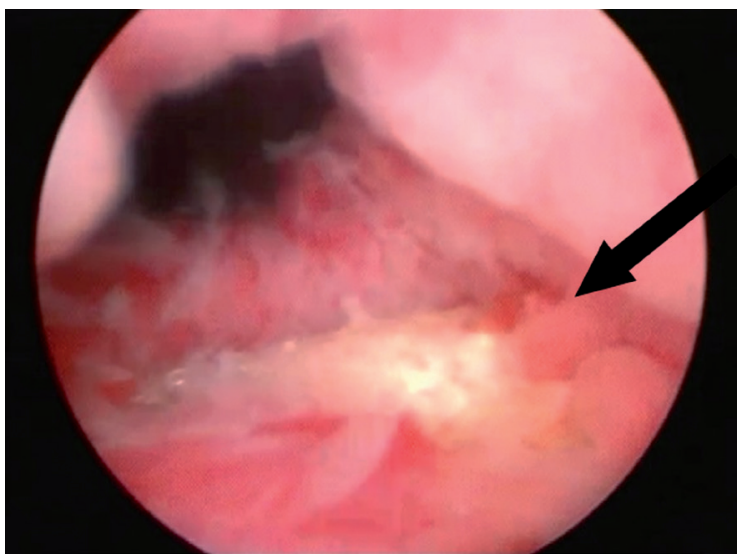


urethral surgery and pelvic radiation are conditions that determine worse urethral vitality and may contribute to a higher risk of erosion $(55,56)$. Treatment requires mesh removal and urethral repair (56). Total removal is usually performed by vaginal surgery. Laparoscopy may be used in selected cases of retropubic slings (57). Transvaginal partial removal is indicated for small erosions with little tissue loss and absence of infection. An endoscopic approach has also been proposed, consisting in removing the eroded mesh transurethrally and keeping a urethral catheter for 7-14 days (Figure-5) (58$60)$. In cases requiring urethral reconstruction with extensive tissue mobilization and long suture lines, a Martius flap should be associated to minimize the risk of a fistula $(61,62)$.

Figure 5 - Endoscopic treatment of mesh erosion in the bladder using laparoscopic scissors (arrow).

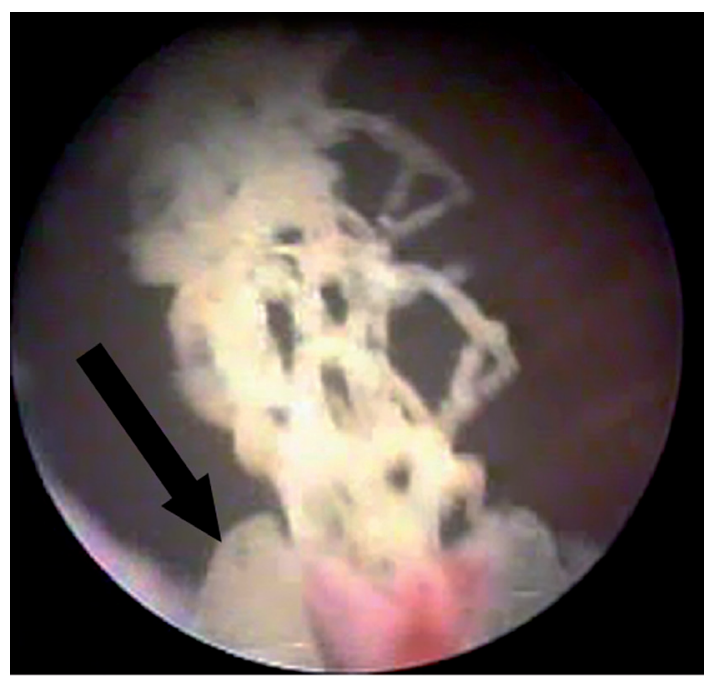

Voiding dysfunction after mesh removal is common. Starkman et al. evaluated 19 patients and reported that only 4 (21\%) became completely asymptomatic after mesh removal. SUI recurred in 8 (42\%) patients and only $9(47 \%)$ considered themselves to be completely dry after surgery (63). Velemir et al. reviewed 17 cases of urethral erosion and obtained only 35.3\% of complete urinary continence after transvaginal mesh removal (64). The same authors obtained a continence rate of $57.1 \%$ after endoscopic mesh removal. These results may reflect a milder severity of the erosion in patients who underwent endoscopic treatment. According to all authors, the simultaneous placement of a new SSS is contraindicated $(15,65)$. An autologous pubovaginal sling, however, may be considered $(56,63)$.

\section{Bowel injury}

Bowel perforation is a life-threatening complication that has only been described with the retropubic technique. Few cases have been reported, with an estimated incidence of $0.03 \%$ to $0.7 \%(18,66-68)$. The most important risk factor is previous pelvic surgery, which supposedly increases the risk of bowel fixation in the retropubic area. Clinical presentation may include abdominal pain, fever, malaise, leukocytosis, sepsis and bowel fluid discharge from the surgical wound.

Treatment consists of exploratory laparotomy for bowel repair and sling removal. A temporary bowel diversion may be warranted in cases with later diagnosis and bad tissue quality in which a primary repair is considered of high risk. It should be noted that the fact that the transobturator technique avoids the retropubic space makes this serious complication virtually impossible.

\section{Vaginal extrusion}

Vaginal extrusion rates vary from $0 \%$ to $1.5 \%$ for the retropubic slings $(28,29)$ and from $0 \%$ to $10.9 \%$ for the transobturator $(27,69,70)$. Regardless of the route used, the risk factors include inadequate closure of the vaginal incision, atrophic vaginal mucosa, local infection and unrecognized vaginal lesions during needle passage (17).

Vaginal extrusion (Figure-6) rates depend greatly on the type of synthetic mesh used. Polypropylene monofilament, malleable and macropore meshes are the standard meshes used in contemporary sling surgeries. They have been associated with lower extrusion rates in comparison to other meshes that were used in the past $(71,72)$. Those characteristics promote better tissue incorporation and facilitate local immune reaction reducing the risk of local infection. When extrusion is associated with infection, 
Figure 6 - Vaginal extrusion (arrow) of mesh at the left anterolateral vaginal wall.

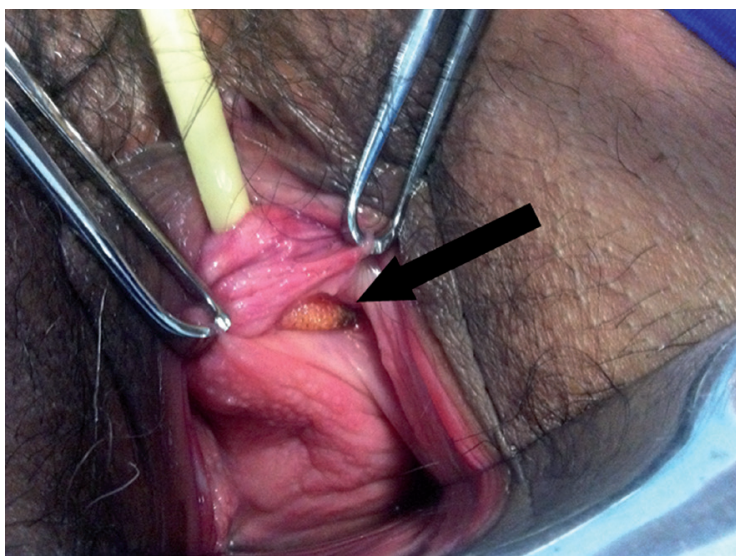

patients generally present with local pain, vaginal discharge and dyspareunia. The extruded mesh may be identified during vaginal examination. This presentation usually occurs within the first postoperative months and must be distinguished from that which occurs early and, in general, is caused by wound dehiscence, inadequate closure or inadvertent needle passage in the vaginal wall that remained unrecognized during surgery $(66$, 73, 74).

If the extrusion is small and not associated with infection, conservative treatment and sexual abstinence may be adopted in order to permit second intention healing, with resolution in few weeks (75). Topical estrogen appears to improve the outcomes of conservative treatment (72). Authors recommend surgical removal of the eroded mesh segment if conservative treatment failed and when local infection is suspected $(62,76)$. This technique is accompanied by high resolution rates and the chance of recurrent stress urinary incontinence is very low. Reintervention for total mesh removal should be considered in cases of recurrence after the initial procedure (23). Erosions presenting with thorough purulent vaginal discharge, extensive vaginal inflammation or signs of systemic infection require aggressive treatment with total mesh removal (Figure-7). In this situation, the rates of recurrent stress urinary incontinence are approximately 20\% (77).
Figure 7 - Transvaginal removal of an infected and extruded sling mesh (arrow).

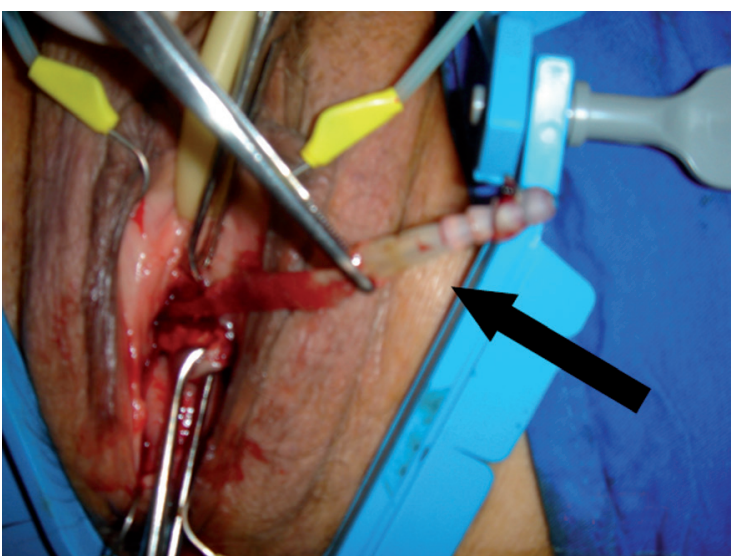

\section{Urinary tract infection (UTI)}

Recurrent UTIs after SSS surgery may represent a complication secondary to the presence of urethral/bladder erosion or bladder outlet obstruction. Anger et al. reported that 33.6\% of the patients who underwent sling surgery had a UTI within the first 3 postoperative months, which increased to 46.7\% within the first 12 months (66). Recently, other authors reported lower rates, ranging from $7.4 \%$ to $13 \%$, with no significant difference between the retropubic and transobturator techniques $(4,24,27,28)$. Cases of recurrent UTI due to bladder outlet obstruction require surgical treatment, including mesh lysis or even urethrolysis, as needed. In cases of erosion, removal of the eroded sling and urethral reconstruction are indicated.

\section{Surgical Site Infection}

Surgical site infections after a SSS are rarely described and include superficial soft tissue infection and deep abscesso (78, 79). Clinical manifestations of these infections may include pain, tenderness, swelling (Figure-8) and fever, which begins during the first week after the procedure (80). It is easily identified during physical examination and the treatment is based on the use of large spectrum antibiotics (81). Occasionally, ultra-sonography, computer tomography or magnetic ressonance imaging may be used to evaluate the presence of an abscess and 
Figure 8 - Large subcutaneous abscess (arrow) after transobturatory SSS treated with ultrasound guided puncture.

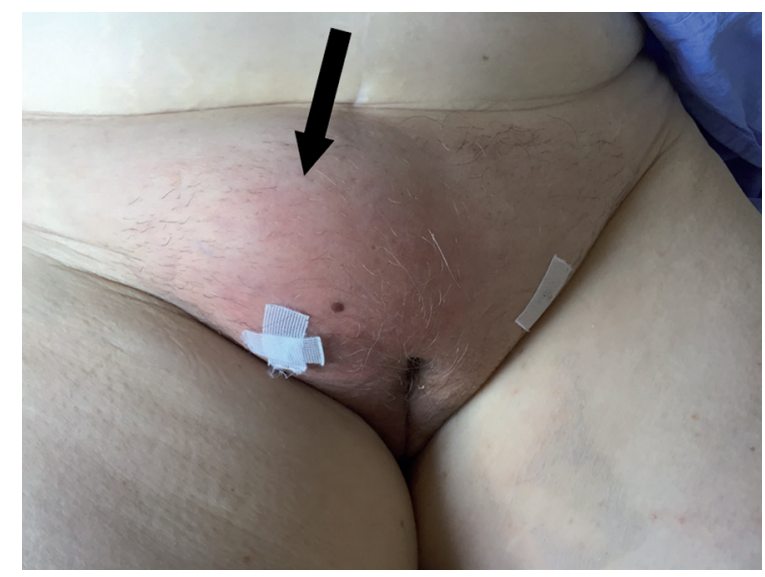

its exact extension as well as to guide its drainage (82). Although surgical site infections generally occur in the early postoperative period, cases of deep infections with delayed presentation have been described (82). Noteworthy, cases of severe necrotizing fasciitis after a SSS procedure has also been described $(83,84)$.

\section{Postoperative pain}

Pain in the groin and thighs is one of the most common complications of suburethral sling procedures. The TOMUS trial, a prospective series of 597 patients followed-up for 12 months, comparing the transobturator and retropubic techniques, showed a lower incidence of so called neurological symptoms (pain) for the retropubic slings (4.0\%) compared to the transobturator ones (9.4\%) (85). In most cases, pain disappears within the first weeks after surgery, but it may persist for more than 4 weeks in $1 \%$ to $2.7 \%$ of the patients $(12,52,70,86)$.

Several factors may contribute to postoperative pain such as needle passage through pelvic muscles, infection, haematoma, and, more rarely, obturator nerve injury, a complication observed in less than $1 \%$ of the cases (24).

It was hypothesized that the inflammatory reaction of the sling material may lead to tissue retraction and hypertonia of the obturator muscle, which may simulate a pinched pudendal nerve, inducing groin and perineal pain $(87,88)$.
Treatment should be directed to the etiological factor and may vary from the use of common analgesics until drainage of an abscess or haematoma $(24,55,89-91)$. In cases of severe or persistent infection, sling removal must be considered. Additionally, occasional patients that persist with pain despite adequate conservative treatment may also be considered for sling removal $(23,92)$.

\section{De novo urgency}

Postoperative urgency is a common complication after SSS procedures, with rates ranging from 5.9 to 25\% for the retropubic technique (93, 94) and from 0 to $15.6 \%$ for the transobturator slings $(27,95)$. When considering treatment for this condition, one should first exclude the possibility of sling erosion, local hematoma or bladder outlet obstruction. In these cases, treatment should be directed to the cause. If urethrolysis is required because of bladder obstruction, urgency symptoms may improve in up to $85 \%$ of the cases (96). When conditions such as sling erosion, urinary tract infection and bladder outlet obstruction have been ruled out, the principles of clinical management of urgency symptoms should follow those used for patients with the overactive bladder syndrome (97).

\section{Urinary retention}

Urinary retention is a common early postoperative complication of all surgical procedures for SUI. Its prevalence varies from 2.5 to $19.5 \%$ for retropubic $(2,55,93,98)$ and from 1.5 to $8.6 \%$ for transobturator slings $(4,24,27)$. The majority of these patients present transient voiding dysfunction with spontaneous resolution in a period of 48 hours to 21 days. The initial management should be to provide a bladder emptying method (indwelling catheter or clean self intermittent catheterization). However, 0.3 to $4.5 \%$ of patients treated with a SSS persist with urinary retention for more than 4 weeks and require surgical mesh lysis $(2,4,24,27,55,93,98)$.

\section{Bladder outlet obstruction (BO0)}

Bladder outlet obstruction can be easily suspected when patients present with persistent urinary retention (longer than 4 weeks) or have 
overt symptoms of incomplete emptying, weak urinary stream and straining to void. However, a significant number of patients demonstrate less evident symptoms and the diagnosis often requires a high index of suspicion, frequently triggered by presentation with symptoms such as urgency, frequency and nocturia. The diagnosis of BOO in women may be challenging and should be made by taking into account the history, physical examination, imagining of the lower urinary tract and the urodynamic pressure-flow parameters (Figure-9a) $(99,100)$. transobturator sling $(0 \% ; p=0.004)$ (85). The surgical options for B00 after a SSS surgery include sling incision (Figures 9b and 9c), sling lysis and partial removal and extensive vaginal or retropubic urethrolysis, with removal of the sling and disruption of the fibrosis surrounding the urethra and bladder neck (Figure-10). When outlet obstruction is diagnosed a long time after sling surgery, single mesh transection may be insufficient to improve B00 because of the possible fixation of the urethra to the pubis and the periurethral fibrotic process. In these cases,

Figure 9a - Urodynamics findings of a patient with B00 secondary to a retropubic SSS, showing high detrusor pressures (short arrow) and low maximum flow rate (long arrow).

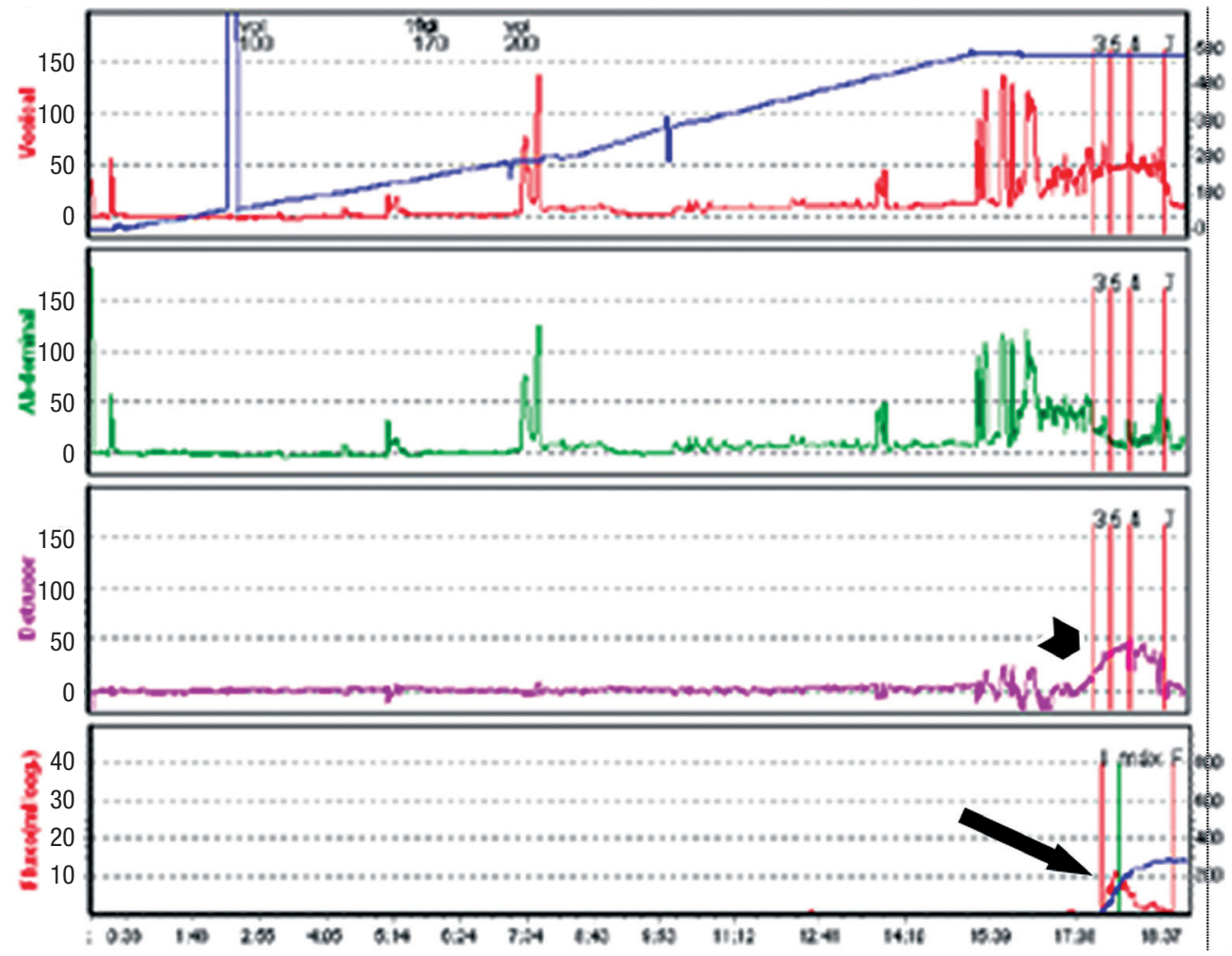

In order to improve symptoms and to prevent progression of bladder dysfunction, postoperative B00 should be surgically relieved. The Tomus trial showed higher reoperation rates for treatment of voiding dysfunction in patients undergoing retropubic sling (2.7\%) compared to those who underwent urethrolysis associated with mesh transection is recommended, with satisfactory results ranging from 70 to $85 \%$ and SUI recurrence in about $19 \%$ (96). If a second urethrolysis is needed, the resolution rate is about $92 \%$, with recurrence of incontinence similar to the observed after the first one (22\%) (101). 
Figure $9 \mathrm{~b}$ - Sling incision (arrow) in the same patient after vaginal incision.

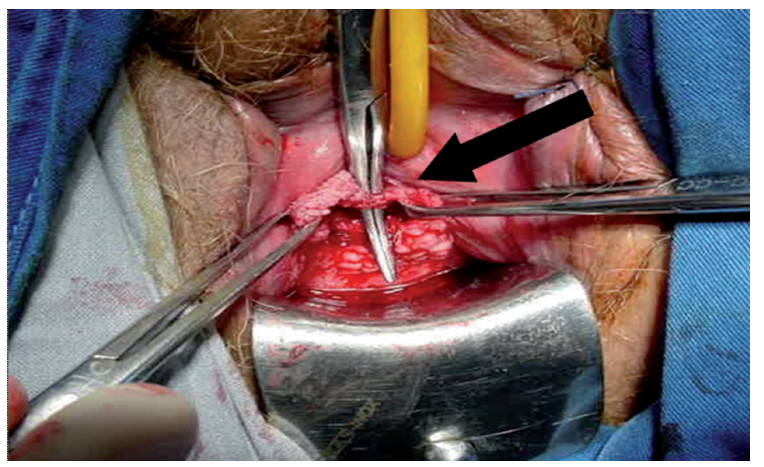

thus become a major concern to all vaginal surgeons. Given the potential risks involved, as well as the readily available legal recourse for patients who experience complications, it is important to deter litigation by appropriately counseling patients about the risks and documenting informed consent in the medical record (102-106).

\section{CONCLUSIONS}

This review highlights the surgical morbidity of synthetic suburethral slings, which may include bothersome and even life-threatening complications.

Figure 9c - Postoperative urodynamics demonstrates resolution of the B00, with low detrusor pressures (PdetQmax 8cm H2O - short arrow) and good flow (Qmax $42 \mathrm{~mL} / \mathrm{s}$ - long arrow).

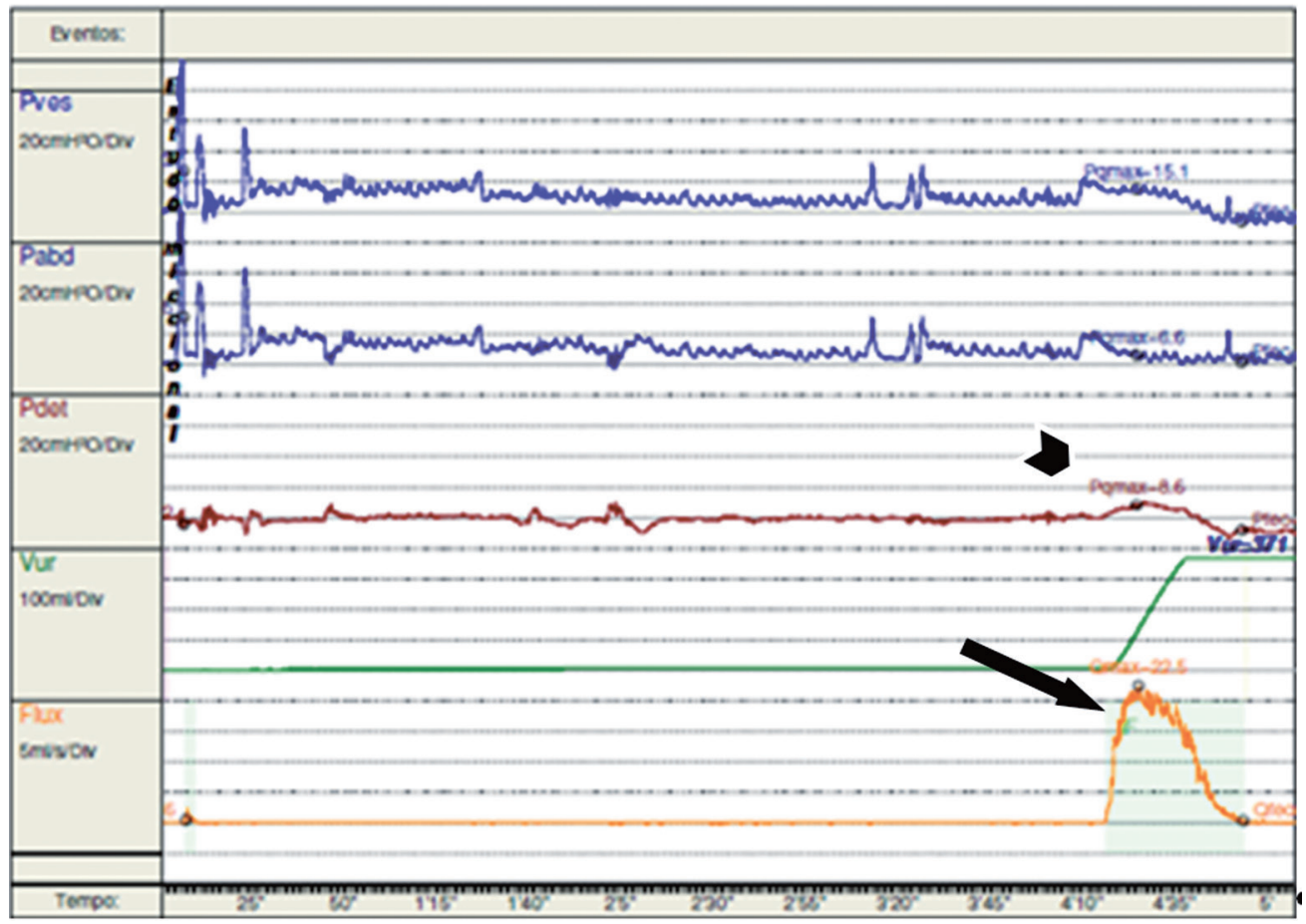

Medicolegal problems with vaginal mesh surgery

In addition to the medical problems, surgeons must be aware of potential litigation resulting from complications of vaginal surgeries with implantation of meshes. Since the FDA released a warning on the safety and effectiveness of transvaginal placement of meshes in 2011, the number of lawsuits has increased exponentially and has
There is an increasing body of evidence to suggest that the number and severity of complications are underestimated, both by surgeons and patients.

As SSS surgery is the most common procedure performed for the treatment of female stress urinary incontinence, urologists and gynecologists must be aware of these complications, the strategies to avoid them and how to appropriately diagnose and manage the complications. Moreover, to lessen 
the chance of medicolegal problems, surgeons using transvaginal meshes should inform patients of potential complications associated with the products and document informed consent in their medical records.

\section{CONFLICT OF INTEREST}

\section{None declared.}

\section{REFERENCES}

1. Norton P, Brubaker L. Urinary incontinence in women. Lancet. 2006;367:57-67.

2. Abouassaly $R$, Steinberg JR, Lemieux M, Marois $C$, Gilchrist LI, Bourque JL, et al. Complications of tension-free vaginal tape surgery: a multi-institutional review. BJU Int. 2004;94:110-3.

3. Ballert KN, Rose AE, Biggs GY, Rosenblum N, Nitti VW. Outcomes of patients lost to followup after mid urethral synthetic slings--successes or failures? J Urol. 2010;183:1455-8.

4. Barry C, Lim YN, Muller R, Hitchins S, Corstiaans A, Foote A, et al. A multi-centre, randomised clinical control trial comparing the retropubic (RP) approach versus the transobturator approach (TO) for tension-free, suburethral sling treatment of urodynamic stress incontinence: the TORP study. Int Urogynecol J Pelvic Floor Dysfunct. 2008;19:171-8.

5. Daraï E, Frobert JL, Grisard-Anaf M, Lienhart J, Fernandez H, Dubernard G, et al. Functional results after the suburethral sling procedure for urinary stress incontinence: a prospective randomized multicentre study comparing the retropubic and transobturator routes. Eur Urol. 2007;51:795-801.

6. Palma P, Riccetto C, Herrmann V, Dambros M, Thiel M, Bandiera S, et al. Transobturator SAFYRE sling is as effective as the transvaginal procedure. Int Urogynecol J Pelvic Floor Dysfunct. 2005;16:487-91.

7. Tseng LH, Wang AC, Lin YH, Li SJ, Ko YJ. Randomized comparison of the suprapubic arc sling procedure vs tension-free vaginal taping for stress incontinent women. Int Urogynecol J Pelvic Floor Dysfunct. 2005;16:230-5.

8. Tsivian A, Mogutin B, Kessler 0, Korczak D, Levin S, Sidi AA. Tension-free vaginal tape procedure for the treatment of female stress urinary incontinence: long-term results. J Urol. 2004;172:998-1000.

9. Rehman H, Bezerra CC, Bruschini H, Cody JD. Traditional suburethral sling operations for urinary incontinence in women. Cochrane Database Syst Rev. 2011;1:CD001754.

10. Blaivas JG, Purohit RS, Benedon MS, Mekel G, Stern M, Billah $M$, et al. Safety considerations for synthetic sling surgery. Nat Rev Urol. 2015;12:481-509.
11. Petros PP. The intravaginal slingplasty operation, a minimally invasive technique for cure of urinary incontinence in the female. Aust N Z J Obstet Gynaecol. 1996;36:453-61.

12. Latthe PM, Foon R, Toozs-Hobson P. Transobturator and retropubic tape procedures in stress urinary incontinence: a systematic review and meta-analysis of effectiveness and complications. BJOG. 2007;114:522-31. Review. Erratum in: BJOG. 2007;114:1311.

13. Ulmsten $U$, Henriksson $L$, Johnson P, Varhos $G$. An ambulatory surgical procedure under local anesthesia for treatment of female urinary incontinence. Int Urogynecol J Pelvic Floor Dysfunct. 1996;7:81-5.

14. Delorme E. Transobturator urethral suspension: miniinvasive procedure in the treatment of stress urinary incontinence in women. Prog Urol. 2001;11:1306-13.

15. Dmochowski RR, Blaivas JM, Gormley EA, Juma S, Karram MM, Lightner DJ, et al. Update of AUA guideline on the surgical management of female stress urinary incontinence. J Urol. 2010;183:1906-14.

16. Ayoub N, Chartier-Kastler E, Robain G, Mozer P, Bitker MO, Richard F. [Functional consequences and complications of surgery for female stress urinary incontinence]. Prog Urol. 2004;14:360-73.

17. Daneshgari F, Kong W, Swartz M. Complications of mid urethral slings: important outcomes for future clinical trials. J Urol. 2008;180:1890-7.

18. Kobashi KC, Govier FE. Perioperative complications: the first 140 polypropylene pubovaginal slings. J Urol. 2003;170:1918-21.

19. Sweat SD, Itano NB, Clemens JQ, Bushman W, Gruenenfelder $\mathrm{J}$, McGuire EJ, et al. Polypropylene mesh tape for stress urinary incontinence: complications of urethral erosion and outlet obstruction. J Urol. 2002;168:144-6.

20. Volkmer BG, Nesslauer T, Rinnab L, Schradin T, Hautmann RE, Gottfried HW. Surgical intervention for complications of tension-free vaginal tape procedure. J Urol. 2003;169:570-4.

21. Clemens JQ, DeLancey JO, Faerber GJ, Westney OL, Mcguire EJ. Urinary tract erosions after synthetic pubovaginal slings: diagnosis and management strategy. Urology. 2000;56:589-94.

22. Hampel C, Naumann G, Thüroff JW, Gillitzer R. Management of complications after sling and mesh implantations. Urologe A. 2009;48:496-509.

23. Misrai V, Rouprêt M, Xylinas E, Cour F, Vaessen C, Haertig A, et al. Surgical resection for suburethral sling complications after treatment for stress urinary incontinence. J Urol. 2009;181:2198-202.

24. Barber MD, Gustilo-Ashby AM, Chen CC, Kaplan P, Paraiso MF, Walters MD. Perioperative complications and adverse events of the MONARC transobturator tape, compared with the tension-free vaginal tape. Am J Obstet Gynecol. 2006;195:1820-5. 
25. Boyles SH, Edwards R, Gregory W, Clark A. Complications associated with transobturator sling procedures. Int Urogynecol J Pelvic Floor Dysfunct. 2007;18:19-22.

26. Novara G, Galfano A, Boscolo-Berto R, Secco S, Cavalleri S, Ficarra $V$, et al. Complication rates of tension-free midurethral slings in the treatment of female stress urinary incontinence: a systematic review and meta-analysis of randomized controlled trials comparing tension-free midurethral tapes to other surgical procedures and different devices. Eur Urol. 2008;53:288-308.

27. Fischer A, Fink T, Zachmann S, Eickenbusch U. Comparison of retropubic and outside-in transoburator sling systems for the cure of female genuine stress urinary incontinence. Eur Urol. 2005;48:799-804.

28. Laurikainen E, Valpas A, Kivelä A, Kalliola T, Rinne K, Takala T, et al. Retropubic compared with transobturator tape placement in treatment of urinary incontinence: a randomized controlled trial. Obstet Gynecol. 2007;109:4-11.

29. Porena M, Costantini E, Frea B, Giannantoni A, Ranzoni $S$, Mearini L, et al. Tension-free vaginal tape versus transobturator tape as surgery for stress urinary incontinence: results of a multicentre randomised trial. Eur Urol. 2007:52:1481-90.

30. Tommaselli GA, Di Carlo C, Formisano C, Fabozzi A, Nappi C. Medium-term and long-term outcomes following placement of midurethral slings for stress urinary incontinence: a systematic review and metaanalysis. Int Urogynecol J. 2015;26:1253-68.

31. Lee D, Zimmern PE. Management of complications of mesh surgery. Curr Opin Urol. 2015;25:284-91.

32. Urogynecologic Surgical Mesh: Update on the Safety and Effectiveness of Transvaginal Placement for Pelvic Organ Prolapse. In; 2011. available at. <http://www.fda. gov/downloads/medicaldevices/safety/alertsandnotices/ UCM262760.pdf>

33. Barber MD, Kleeman S, Karram MM, Paraiso MF, Walters MD, Vasavada S, Ellerkmann M. Transobturator tape compared with tension-free vaginal tape for the treatment of stress urinary incontinence: a randomized controlled trial. Obstet Gynecol. 2008;111:611-21.

34. Giri SK, Wallis F, Drumm J, Saunders JA, Flood HD. A magnetic resonance imaging-based study of retropubic haematoma after sling procedures: preliminar findings. BJU Int. 2005;96:1067-71.

35. Flock F, Reich A, Muche R, Kreienberg R, Reister F. Hemorrhagic complications associated with tension-free vaginal tape procedure. Obstet Gynecol. 2004;104:989-94.

36. Costa P, Grise P, Droupy S, Monneins F, Assenmacher C, Ballanger $P$, et al. Surgical treatment of female stress urinary incontinence with a trans-obturator-tape (T.O.T.) Uratape: short term results of a prospective multicentric study. Eur Urol. 2004;46:102-6.
37. Barber MD, Kleeman S, Karram MM, Paraiso MF, Walters MD, Vasavada S, et al. Transobturator tape compared with tension-free vaginal tape for the treatment of stress urinary incontinence: a randomized controlled trial. Obstet Gynecol. 2008;111:611-21.

38. Kölle D, Tamussino K, Hanzal E, Tammaa A, Preyer 0, Bader A, et al. Austrian Urogynecology Working Group. Bleeding complications with the tension-free vaginal tape operation. Am J Obstet Gynecol. 2005;193:2045-9.

39. Neuman M. TVT and TVT-Obturator: comparison of two operative procedures. Eur J Obstet Gynecol Reprod Biol. 2007;131:89-92.

40. Seklehner S, Laudano MA, Xie D, Chughtai B, Lee RK. A meta-analysis of the performance of retropubic mid urethral slings versus transobturator mid urethral slings. J Urol. 2015;193:909-15.

41. Deng DY, Rutman M, Raz S, Rodriguez LV. Presentation and management of major complications of midurethral slings: Are complications under-reported? Neurourol Urodyn. 2007;26:46-52.

42. Anast JW, Williams ER, Klutke C. Pelvic hematoma following transobturator tape procedure: case report and review of literature. Can J Urol. 2008;15:3930-2.

43. Ko JK, $\mathrm{Ku} \mathrm{CH}$. Embolization for pelvic arterial bleeding following a transobturator tape procedure. J Obstet Gynaecol Res. 2014;40:865-8.

44. Gold RS, Groutz A, Pauzner D, Lessing J, Gordon D. Bladder perforation during tension-free vaginal tape surgery: does it matter? J Reprod Med. 2007;52:616-8.

45. Kuuva N, Nilsson CG. A nationwide analysis of complications associated with the tension-free vaginal tape (TVT) procedure. Acta Obstet Gynecol Scand. 2002;81:72-7.

46. Tamussino KF, Hanzal E, Kölle D, Ralph G, Riss PA; Austrian Urogynecology Working Group. Tension-free vaginal tape operation: results of the Austrian registry. Obstet Gynecol. 2001;98:732-6.

47. Andonian S, Chen T, St-Denis B, Corcos J. Randomized clinical trial comparing suprapubic arch sling (SPARC) and tension-free vaginal tape (TVT): one-year results. Eur Urol. 2005;47:537-41.

48. Juma S, Brito CG. Transobturator tape (TOT): Two years follow-up. Neurourol Urodyn. 2007;26:37-41.

49. Minaglia S, Ozel B, Klutke C, Ballard C, Klutke J. Bladder injury during transobturator sling. Urology. 2004;64:376-7.

50. Sung VW, Schleinitz MD, Rardin CR, Ward RM, Myers DL. Comparison of retropubic vs transobturator approach to midurethral slings: a systematic review and meta-analysis. Am J Obstet Gynecol. 2007;197:3-11.

51. Dmochowski RR, Blaivas JM, Gormley EA, Juma S, Karram MM, Lightner DJ, et al. Update of AUA guideline on the surgical management of female stress urinary incontinence. J Urol. 2010;183:1906-14. 
52. Collinet $P$, Ciofu C, Costa $P$, Cosson M, Deval B, Grise $P$, et al. The safety of the inside-out transobturator approach for transvaginal tape (TVT-0) treatment in stress urinary incontinence: French registry data on 984 women. Int Urogynecol J Pelvic Floor Dysfunct. 2008;19:711-5.

53. Morton HC, Hilton P. Urethral injury associated with minimally invasive mid-urethral sling procedures for the treatment of stress urinary incontinence: a case series and systematic literature search. BJOG. 2009;116:1120-6.

54. Faiena I, Koprowski C, Tunuguntla H. Female Urethral Reconstruction. J Urol. 2016;195:557-67.

55. Karram MM, Segal JL, Vassallo BJ, Kleeman SD. Complications and untoward effects of the tension-free vaginal tape procedure. Obstet Gynecol. 2003;101:929-32.

56. Blaivas JG, Sandhu J. Urethral reconstruction after erosion of slings in women. Curr Opin Urol. 2004;14:335-8.

57. Gerstenbluth RE, Goldman HB. Simultaneous urethral erosion of tension-free vaginal tape and woven polyester pubovaginal sling. J Urol. 2003;170:525-6.

58. Baracat F, Mitre AI, Kanashiro H, Montellato NI. Endoscopic treatment of vesical and urethral perforations after tensionfree vaginal tape (TVT) procedure for female stress urinary incontinence. Clinics (Sao Paulo). 2005;60:397-400.

59. Werner M, Najjari L, Schuessler B. Transurethral resection of tension-free vaginal tape penetrating the urethra. Obstet Gynecol. 2003;102:1034-6.

60. Wijffels SA, Elzevier HW, Lycklama a Nijeholt AA. Transurethral mesh resection after urethral erosion of tension-free vaginal tape: report of three cases and review of literature. Int Urogynecol J Pelvic Floor Dysfunct. 2009;20:261-3.

61. Elkins TE, DeLancey J0, McGuire EJ. The use of modified Martius graft as na adjunctive technique in vesicovaginal and rectovaginal fistula repair. Obstet Gynecol. 1990;75:727-33.

62. Elkins TE, Ghosh TS, Tagoe GA, Stocker R. Transvaginal mobilization and utilization of the anterior bladder wall to repair vesicovaginal fistulas involving the urethra. Obstet Gynecol. 1992;79:455-60.

63. Starkman JS, Wolter C, Gomelsky A, Scarpero HM, Dmochowski RR. Voiding dysfunction following removal of eroded synthetic mid urethral slings. J Urol. 2006;176:10404. Erratum in: J Urol. 2006;176:2749.

64. Velemir L, Amblard J, Jacquetin B, Fatton B. Urethral erosion after suburethral synthetic slings: risk factors, diagnosis, and functional outcome after surgical management. Int Urogynecol J Pelvic Floor Dysfunct. 2008;19:999-1006.

65. Smith AL, Moy ML. Modern management of women with stress urinary incontinence. Ostomy Wound Manage. 2004;50:32-9.

66. Anger JT, Litwin MS, Wang Q, Pashos CL, Rodríguez LV. Complications of sling surgery among female Medicare beneficiaries. Obstet Gynecol. 2007;109:707-14.

67. Gurtcheff SE. Introduction to the MAUDE database. Clin Obstet Gynecol. 2008;51:120-3.
68. Hodroff MA, Sutherland SE, Kesha JB, Siegel SW. Treatment of stress incontinence with the SPARC sling: intraoperative and early complications of 445 patients. Urology. 2005;66:760-2.

69. David-Montefiore E, Frobert JL, Grisard-Anaf M, Lienhart J, Bonnet K, Poncelet C, et al. Peri-operative complications and pain after the suburethral sling procedure for urinary stress incontinence: a French prospective randomised multicentre study comparing the retropubic and transobturator routes. Eur Urol. 2006;49:133-8.

70. Debodinance P. Trans-obturator urethral sling for surgical correction of female stress urinary incontinence: Outside-in (Monarc) versus inside-out (TVT-0). Are both ways safe?. J Gynecol Obstet Biol Reprod (Paris). 2006;35:571-7.

71. Feifer A, Corcos J. The use of synthetic sub-urethral slings in the treatment of female stress urinary incontinence. Int Urogynecol J Pelvic Floor Dysfunct. 2007;18:1087-95.

72. Kobashi KC, Govier FE. Management of vaginal erosion of polypropylene mesh slings. J Urol. 2003;169:2242-3.

73. Babalola EO, Famuyide AO, McGuire LJ, Gebhart JB, Klingele CJ. Vaginal erosion, sinus formation, and ischiorectal abscess following transobturator tape: ObTape implantation. Int Urogynecol J Pelvic Floor Dysfunct. 2006;17:418-21.

74. Benassi G, Marconi L, Accorsi F, Angeloni M, Benassi L. Abscess formation at the ischiorectal fossa 7 months after the application of a synthetic transobturator sling for stress urinary incontinence in a type II diabetic woman. Int Urogynecol J Pelvic Floor Dysfunct. 2007;18:697-9.

75. Bong GW, Rovner ES. Vaginal erosion after hybrid midurethral sling placement. Urology. 2006;68:1343.e13-4.

76. Deval B, Haab F. Management of the complications of the synthetic slings. Curr Opin Urol. 2006;16:240-3.

77. Domingo S, Alamá P, Ruiz N, Perales A, Pellicer A. Diagnosis, management and prognosis of vaginal erosion after transobturator suburethral tape procedure using a nonwoven thermally bonded polypropylene mesh. J Urol. 2005;173:1627-30.

78. Richter HE, Albo ME, Zyczynski HM, Kenton K, Norton PA, Sirls LT, et al. Retropubic versus transobturator midurethral slings for stress incontinence. N Engl J Med. 2010;362:206676.

79. Borstad E, Abdelnoor M, Staff AC, Kulseng-Hanssen S. Surgical strategies for women with pelvic organ prolapse and urinary stress incontinence. Int Urogynecol J. 2010;21:17986.

80. Daneshgari F, Kong W, Swartz M. Complications of mid urethral slings: important outcomes for future clinical trials. J Urol. 2008;180:1890-7.

81. Shepherd JP, Jones KA, Harmanli O. Is antibiotic prophylaxis necessary before midurethral sling procedures for female stress incontinence? A decision analysis. Int Urogynecol J. 2014;25:227-33. 
82. Babalola EO, Famuyide AO, McGuire LJ, Gebhart JB, Klingele CJ. Vaginal erosion, sinus formation, and ischiorectal abscess following transobturator tape: ObTape implantation. Int Urogynecol J Pelvic Floor Dysfunct. 2006;17:418-21.

83. Connolly TP. Necrotizing surgical site infection after tensionfree vaginal tape. Obstet Gynecol. 2004;104:1275-6.

84. Johnson DW, ElHajj M, OBrien-Best EL, Miller HJ, Fine PM. Necrotizing fasciitis after tension-free vaginal tape (TVT) placement. Int Urogynecol J Pelvic Floor Dysfunct. 2003;14:291-3.

85. Richter HE, Albo ME, Zyczynski HM, Kenton K, Norton PA, Sirls LT, et al. Retropubic versus transobturator midurethral slings for stress incontinence. N Engl J Med. 2010;362:206676.

86. Canel V, Thubert T, Wigniolle I, Fernandez H, Deffieux $X$. Postoperative groin pain and success rates following transobturator midurethral sling placement: TVT ABBREVO® system versus TVTTM obturator system. Int Urogynecol J. 2015;26:1509-16.

87. Itza F, Zarza D, Serra L, Gómez-Sancha F, Salinas J, AllonaAlmagro A. Myofascial pain syndrome in the pelvic floor: a common urological condition. Actas Urol Esp. 2010;34:31826.

88. Pereira-Correia JA, Rodrigues dos Santos CG, BastianPinto BG, Bilouro FC, Facó Hauaji CF, Santos Saud AL, et al. Following the needles: an anatomical study to evaluate the postoperative safety and symptoms of patients receiving a transobturator male sling implant. J Urol. 2014;192:1750-5.

89. Atassi Z, Reich A, Rudge A, Kreienberg R, Flock F. Haemorrhage and nerve damage as complications of TVT-0 procedure: case report and literature review. Arch Gynecol Obstet. 2008;277:161-4.

90. DeSouza R, Shapiro A, Westney OL. Adductor brevis myositis following transobturator tape procedure: a case report and review of the literature. Int Urogynecol J Pelvic Floor Dysfunct. 2007;18:817-20.

91. Yeung $P$ Jr, Sokol A, Walton B, Iglesia C. Thigh abscess mistaken for sarcoma following transobturator tape: a case report and literature review. J Minim Invasive Gynecol. 2007;14:657-9.

92. Wolter CE, Starkman JS, Scarpero HM, Dmochowski RR. Removal of transobturator midurethral sling for refractory thigh pain. Urology. 2008;72:461.e1-3.

93. Jeffry L, Deval B, Birsan A, Soriano D, Daraï E. Objective and subjective cure rates after tension-free vaginal tape for treatment of urinary incontinence. Urology. 2001;58:702-6.

94. Nilsson CG, Kuuva N, Falconer C, Rezapour M, Ulmsten U. Long-term results of the tension-free vaginal tape (TVT) procedure for surgical treatment of female stress urinary incontinence. Int Urogynecol J Pelvic Floor Dysfunct. 2001;12: Suppl 2:S5-8.
95. Delorme E, Droupy S, de Tayrac R, Delmas V. Transobturator tape (Uratape): a new minimally-invasive procedure to treat female urinary incontinence. Eur Urol. 2004;45:203-7.

96. Gomelsky A, Nitti VW, Dmochowski RR. Management of obstructive voiding dysfunction after incontinence surgery: lessons learned. Urology. 2003;62:391-9.

97. Rovner ES, Gomes CM, Trigo-Rocha FE, Arap S, Wein AJ. Evaluation and treatment of the overactive bladder. Rev Hosp Clin Fac Med Sao Paulo. 2002;57:39-48.

98. Levin I, Groutz A, Gold R, Pauzner D, Lessing JB, Gordon D. Surgical complications and medium-term outcome results of tension-free vaginal tape: a prospective study of 313 consecutive patients. Neurourol Urodyn. 2004;23:7-9.

99. McCrery RJ, Appell RA. Bladder outlet obstruction in women: iatrogenic, anatomic, and neurogenic. Curr Urol Rep. 2006;7:363-9.

100. Hoffman DS, Nitti VW. Female Bladder Outlet Obstruction. Curr Urol Rep. 2016;17:31.

101. Scarpero HM, Dmochowski RR, Nitti VW. Repeat urethrolysis after failed urethrolysis for iatrogenic obstruction. J Urol. 2003;169:1013-6.

102. Kuhlmann-Capek MJ, Kilic GS, Shah AB, Diken ZM, Snyder RR, Phelps JY 3rd. Enmeshed in Controversy: Use of Vaginal Mesh in the Current Medicolegal Environment. Female Pelvic Med Reconstr Surg. 2015;21:241-3.

103. Serati M, Bogani G, Braga A, Sorice P, Salvatore S, Uccella $\mathrm{S}$, et al. Is there a learning curve for the TVT-0 procedure? A prospective single-surgeon study of 372 consecutive cases. Eur J Obstet Gynecol Reprod Biol. 2015;186:85-90.

104. Chapple CR, Raz S, Brubaker L, Zimmern PE. Mesh sling in an era of uncertainty: lessons learned and the way forward. Eur Urol. 2013;64:525-9.

105. Osborn DJ, Dmochowski RR, Harris CJ, Danford JJ, Kaufman MR, Mock S, et al. Analysis of patient and technical factors associated with midurethral sling mesh exposure and perforation. Int J Urol. 2014;21:1167-70.

106. Lee D, Bacsu C, Zimmern PE. Meshology: a fast-growing field involving mesh and/or tape removal procedures and their outcomes. Expert Rev Med Devices. 2015;12:201-16.

Correspondence address:

Cristiano Mendes Gomes, MD

Divisão de Clinica Urológica

Hospital das Clínicas da Faculdade de Medicina USP Avenida Dr. Enéas de Carvalho Aguiar, 255 - 710F

São Paulo, SP, 05403-000, Brasil Fax: +55 113064-7013

E-mail: crismgomes@uol.com.br 